\title{
Control of neotectonic movement on hydrocarbon accumulation in the Kuqa Foreland Basin, west China
}

\author{
Jiang Zhenxue, 2*, Li Lianxia ${ }^{1,2}$, Song Yan $^{3}$, Tian Fenghua ${ }^{4}, Z_{\text {hao Mengjun }}^{3}$, \\ Wang Haijiang ${ }^{5}$ and Zhao Zhenxing ${ }^{6}$ \\ ${ }^{1}$ State Key Laboratory of Petroleum Resources and Prospecting, China University of Petroleum, Beijing 102249, China \\ ${ }^{2}$ Basin and Reservoir Research Center, China University of Petroleum, Beijing 102249, China \\ ${ }^{3}$ Exploration and Development Research Institute, PetroChina, Beijing 100083, China \\ ${ }^{4}$ Department of Exploration \& Development, PetroChina CBM Limited Company, Beijing 100013, China \\ ${ }^{5}$ Exploration Department, Tarim Oilfield Company, PetroChina, Kuerle, Xinjiang 841000, China \\ ${ }^{6}$ No. 8 Oil Production Plant, Changqing Oilfield Company, PetroChina, Xi'an, Shaanxi 710018, China \\ (C) China University of Petroleum (Beijing) and Springer-Verlag Berlin Heidelberg 2010
}

\begin{abstract}
Neotectonic movement refers to the tectonic movement that has happened since the Cenozoic, which is the latest movement. It has the most important influence on the basins in west China, especially on the hydrocarbon accumulation in the western foreland basins. We determined the time of neotectonic movement in the Kuqa Foreland Basin, which began from the Neogene, and analyzed the patterns of movement, which were continuous and fast subsidence in the vertical direction and intense lateral compression. The structure styles are that the faulting is weakened and the folding is strengthened gradually from north to south. We studied the control of neotectonic movement on the hydrocarbon accumulation process and model in the Kuqa Foreland Basin with basin simulation technique. The largest subsidence rate of the Kuqa Foreland Basin reached 1,200 m/Ma during the neotectonic movement, leading to rapid maturing of source rock within $5 \mathrm{Ma}$ and a large quantity of hydrocarbon being generated and expelled. The thick neotectonic strata can form high quality reservoirs with the proved gas and oil reserves accounting for $5 \%$ and $27 \%$ of the total reserves, respectively. $86 \%$ of the structural traps were formed in the neotectonic movement period. The faults formed during the neotectonic movement serve as important migration pathways and they exist in the region where the hydrocarbon reservoirs are distributed. Abnormally high pressure caused by the intense lateral compression, thick neotectonic strata deposition and rapid hydrocarbon generation provide driving force for hydrocarbon migration. The accumulation elements match each other well over a short period, leading to many large gas fields formed later in the Kuqa Foreland Basin.
\end{abstract}

Key words: Kuqa Foreland Basin, neotectonic movement, accumulation element, accumulation process, accumulation model

\section{Introduction}

Neotectonic movement has drawn more and more attention recently and new achievements have been made in the study of hydrocarbon accumulation, crust stability, ecological environment and engineering construction (Jia et al, 2008; Cheng et al, 2007; Zhang et al, 2007; Song and Wang, 2003). Great progress has been made in the controlling effect of neotectonic movement on late hydrocarbon accumulation. Many foreign geologists have studied from different angles, such as the rapid maturation of source rocks,

*Corresponding author. email: jiangzx@cup.edu.cn

Received September 4, 2009 volcanism and hydrocarbon accumulation under the effect of neotectonic movement (Kontorovich, 2009; Redfield et al, 2004; Kirillova, 2003). Chinese geologists also paid attention to the controlling effect of neotectonic movement on gas accumulation in China, such as the control of neotectonic movement on late gas accumulation, including new driving force, new traps, the formation of migration pathways and fast charging of hydrocarbon (Song and Wang, 2003; Qin et al, 2006; Zheng et al, 2005; Guo and Shi, 2001; Pang, 2008; Pang et al, 2008; Jiang et al, 2007; Li et al, 2006; Hao et al, 2006). However, little research has been done on the manifestation of neotectonic movement and its control on the hydrocarbon accumulation process in the Kuqa Foreland Basin. Thus determining the starting time, movement pattern 
and structural style of neotectonic movement and its effect on hydrocarbon accumulation conditions and processes in the Kuqa Foreland Basin is very important for studying accumulation mechanisms, establishing an accumulation model based on neotectonic movement and predicting favorable exploration targets.

\section{Time and manifestation of neotectonic movement in the Kuqa Foreland Basin}

The Kuqa Foreland Basin is located in the northern Tarim
Basin in west China, and extends in the NEE direction. It is $450 \mathrm{~km}$ long, $50-80 \mathrm{~km}$ wide, with an area of $2.8 \times 10^{4}$ $\mathrm{km}^{2}$. Multi-stage movements have occurred in the basin and the neotectonic movement has the greatest impact on the structural deformation of the basin. The multi-stage movements led to the tectonic framework of "five belts and three sags". These are the northern monoclinal structural belt, Kelasu tectonic belt, Yiqikelike tectonic belt, Qiulitage anticlinal belt, front uplift belt, and the Baicheng, Yangxia and Wushi sags (Fig. 1).

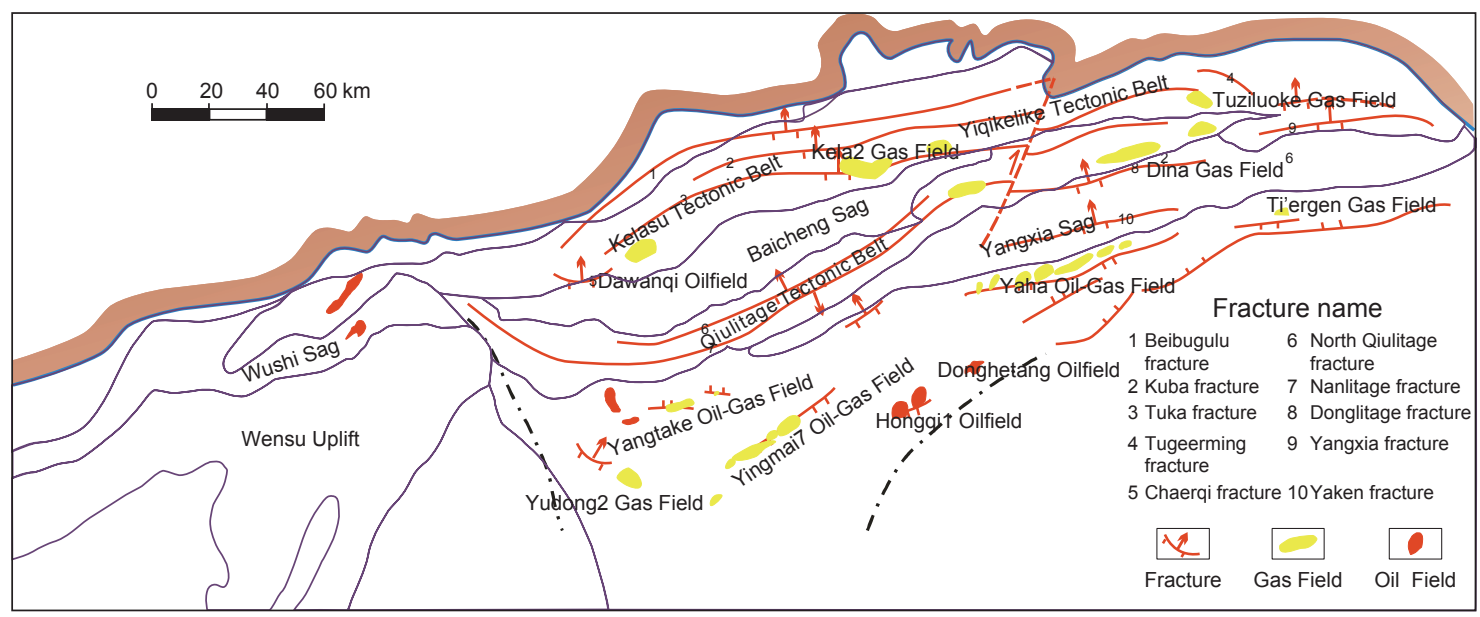

Fig. 1 Regional tectonics and hydrocarbon distribution in the Kuqa Foreland Basin

\subsection{Time of neotectonic movement in the Kuqa Foreland Basin}

Neotectonic movement refers to the tectonic movement that has happened since the Cenozoic (Jia et al, 2004; Qiang and Wang, 1992; Guo et al, 1999). It is generally recognized that the neotectonic movement belongs to the latest stage of geotectonic movement and is in the evolution stage of the latest crustal deformation and orogenic movement. It serves as a link between the past (paleotectonics) and the present (modern tectonics), and can indicate the future trend of crust movement (Lykousis et al, 1995; Granja et al, 1999; Glover and Robertson, 1998). The starting time of neotectonic movement is usually related to that of the modern plate profile or the stress field of an area (Li, 2006). Chinese continental crust has suffered compression in four directions by the plate movement since the Neogene. The Kuqa Foreland Basin formed under the long-distance effect of the India-Tibet plate movement. Previous opinions about the deformation time of different tectonic belts in the Kuqa Foreland Basin are as follows. The tectonic belts in the Kuqa Basin did not move at the same time, but moved gradually and regularly from foreland to basin, from north to south. The deformation in the Jidike period (25 Ma) only happened in the Dongfeng anticlinal belt and the east of northern anticlinal belt, and led to the formation of anticlines in the Dongfeng anticlinal belt and the Yiqikelike anticline in the east of northern anticlinal belt. The deformation in the Kangcun period (16.9 Ma) and Kuqa period (5.3 Ma) extended to the northern anticlinal belt and led to the formation of the anticlines in the northern anticlinal belt, and at this time only the Yiqikelike anticline stopped growing. The deformation in the late Kuqa period (3.7 Ma) extended to the north margin of the Baicheng-Yangxia synclinal belt and the Dawanqi salt anticline was formed. The deformation in the Xiyu period (2.5 Ma) extended to the southern anticline belt and led to the formation of the Qiulitage anticline, and the Yaken anticline located in the southernmost part of the regenerative foreland thrust belt began to form in the late Xiyu period (Liu et al, 1999; Lu et al, 1999; Zhou, 2002; Zhang et al, 2003; Hao et al, 2006; Jin et al, 2007; Tang et al, 2008). Therefore, the neotectonic movement in the Kuqa Foreland Basin lasts from the Neogene to the present, and becomes intense from the late Pliocene.

\subsection{Manifestation of neotectonic movement in the Kuqa Foreland Basin}

The neotectonic movement has two movement patterns in the Kuqa Foreland Basin. One is continuous and fast subsidence in the vertical direction. The subsidence of this basin occurred mainly in the Kuqa period, and the maximum subsidence rate in the Baicheng sag is $1,200 \mathrm{~m} / \mathrm{Ma}$ and that in the Yangxia sag is $1,060.6 \mathrm{~m} / \mathrm{Ma}$. The subsidence center is in the Baicheng sag and its nearby structures. The other pattern is intense compression in the lateral direction. During the neotectonic movement, the northern margin of the Tarim plate moved rapidly to the north, leading to the strata shortening in the north margin of the Tianshan Mountain. The statistics of average shortening amount and shortening rate of 25 balanced cross sections in the Kuqa Foreland Basin show that the strata shortening amount and shortening rate have increased greatly 
since the Neogene, especially since the Quaternary.

Because of the existence of a thick Cenozoic gypsum-salt evaporite layer, the Kuqa Foreland Basin can be divided into two structural layers: above salt and below salt. "Salt" is used here to mean the gypsum/salt evaporite deposits.

Previous researchers have studied the structural styles of Kuqa Foreland Basin a lot, and it is generally believed that the structural styles of the basin are complicated and the layer above salt, salt layer and the layer below salt have different structural styles. The structural styles developed in the layer above salt are anticline above salt, thrust fault above salt, fault-related fold, back thrust fault block, forced fold and salt nappe. The salt layer mainly develops salt pillow structure, fault-fold structure, salt welding structure and salt mat. The layer below salt mainly develops back thrust fault block, fault-related fold, imbricate thrust belt and duplex structure (Zhou, 2002; Zhang et al, 2003; Jin et al, 2007; Tang et al, 2003; 2008; Liu et al, 2000; Sun et al, 2003; Zheng et al,
2008; Qi et al, 2009).

There are six structural styles caused by the neotectonic movement: duplex structure and passive-roof duplex structure, imbricate thrust fault, pop-up structure, faultrelated fold, wedge structure and diapiric anticline (Zhou, 2002; Zhang et al, 2003; Jin et al, 2007; Tang et al, 2008; Gao and Zhao, 2001; Liu et al, 2000; Sun et al, 2003; Yu et al, 2005; Zheng et al, 2008; Qi et al, 2009; Xu et al, 2009) (Fig. 2). Different structural styles are distributed in different structural positions in the Kuqa Basin. The strike-slip fault leads to different structural characteristics between the west and the east of the Kuqa Basin, and the deformation in the west is more intense than that in the east. The Kuqa Basin is also north-south zoned. The faulting weakens from north to south while the folding strengthens. Structures in the north of the basin are mainly fractures associated with folds, in the central part are mainly folds associated with fractures, and in the south are only folds.

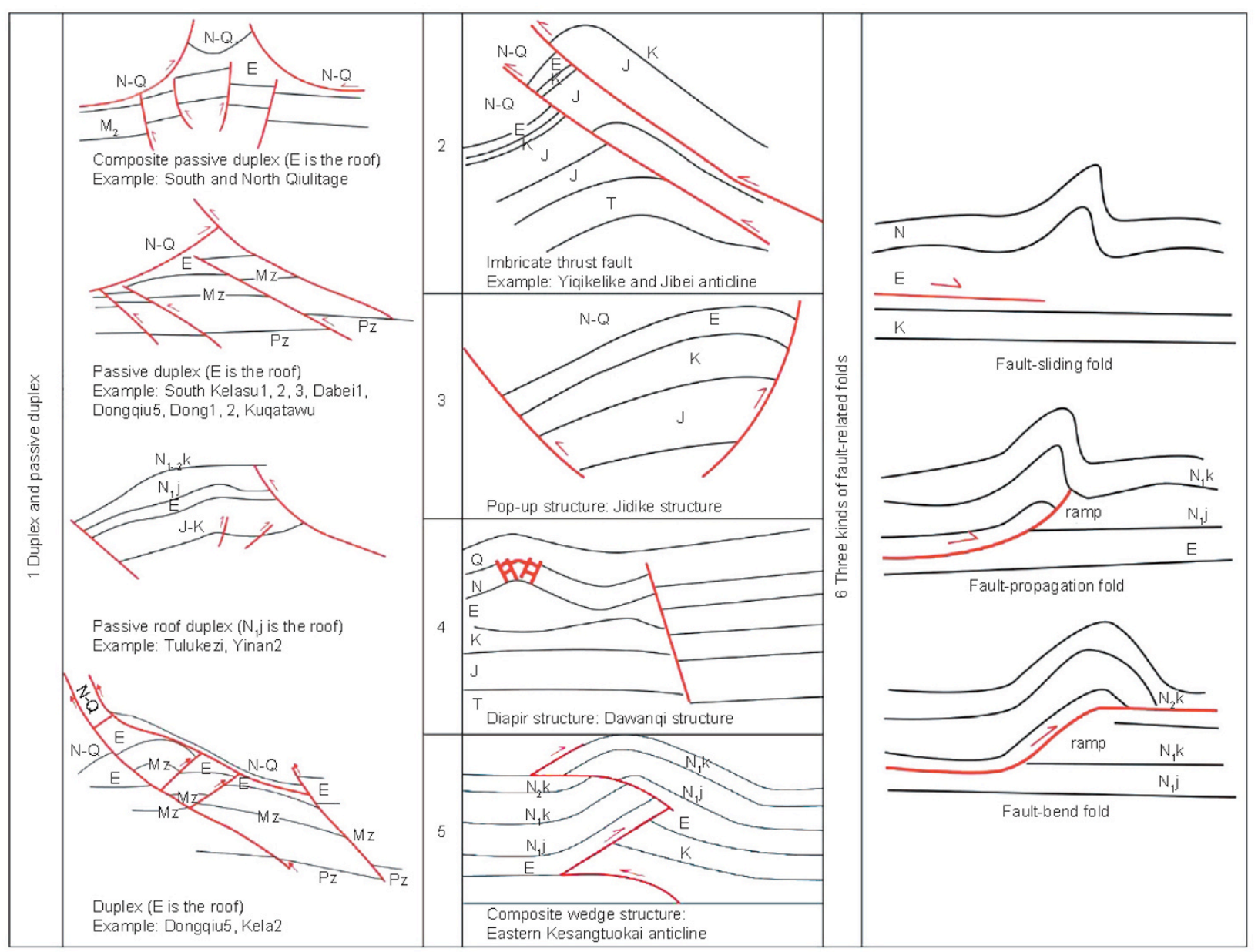

Fig. 2 Structural styles caused by neotectonic movement in the Kuqa Foreland Basin

3 Control of neotectonic movement on hydrocarbon accumulation in the Kuqa Foreland Basin

All the accumulation elements in the Kuqa Foreland Basin are influenced by the neotectonic movement, mainly construction and subsequent transformation. The accumulation elements match each other well in a short period because of the short and intense tectonic movement.

\subsection{Rapid burying accelerated the evolution of source rock}

Thick overlying strata were formed because of the continuous and rapid subsidence during the neotectonic 
movement in the Kuqa Foreland Basin. Besides, the strata thickened because of the structural superposition of the overthrust belt, which made the burial depth of source rock and the strata temperature increase quickly. The degree of increase varied in different tectonic belts, for example, the temperature in the Ke-Yi tectonic belt which had the most intense tectonic movement and the Baicheng sag which subsided rapidly changed the fastest.

Thus, the source rock became mature rapidly and a large quantity of hydrocarbon was generated and expelled in a short time. The maturity of source rock $R_{0}$ changes from $0.5 \%-1 \%$ before the neotectonic movement to $1.8 \%-3.05 \%$ at present, which is the over mature stage. Take the Baicheng sag for example, the maturing rate of source rock was $0.007 \% R_{0} / \mathrm{Ma}$ before the neotectonic movement, $0.03 \% R_{0} / \mathrm{Ma}$ at the beginning of the neotectonic movement, and $0.12 \% R_{0} / \mathrm{Ma}$ (17 times larger than that before the tectonic movement) in the intense stage of neotectonic movement (Song et al, 2000). So the neotectonic movement has a significant impact on source rock maturity. The source rock maturity and maturing rate in the Kuqa Basin increased from north to south, and the Baicheng sag had the largest $R_{0}$ and the highest maturity (Fig. 3 ). The depositional thickness of the neotectonic layer in the Kuqa Foreland Basin is closely related to the present maturity of the Jurassic hydrocarbon source rock. The source rock has high maturity in the area where the neotectonic layer is thick. The contours of source rock maturity and the neotectonic layer thickness have the same trend, which indicates that the thick sedimentation has a great impact on the evolution of underlying hydrocarbon source rock (Fig. 4). The Triassic and Jurassic source rocks have different hydrocarbon generation and expulsion time, but both of their gas generation peaks happened in the Neogene, that is, the neotectonic movement period.
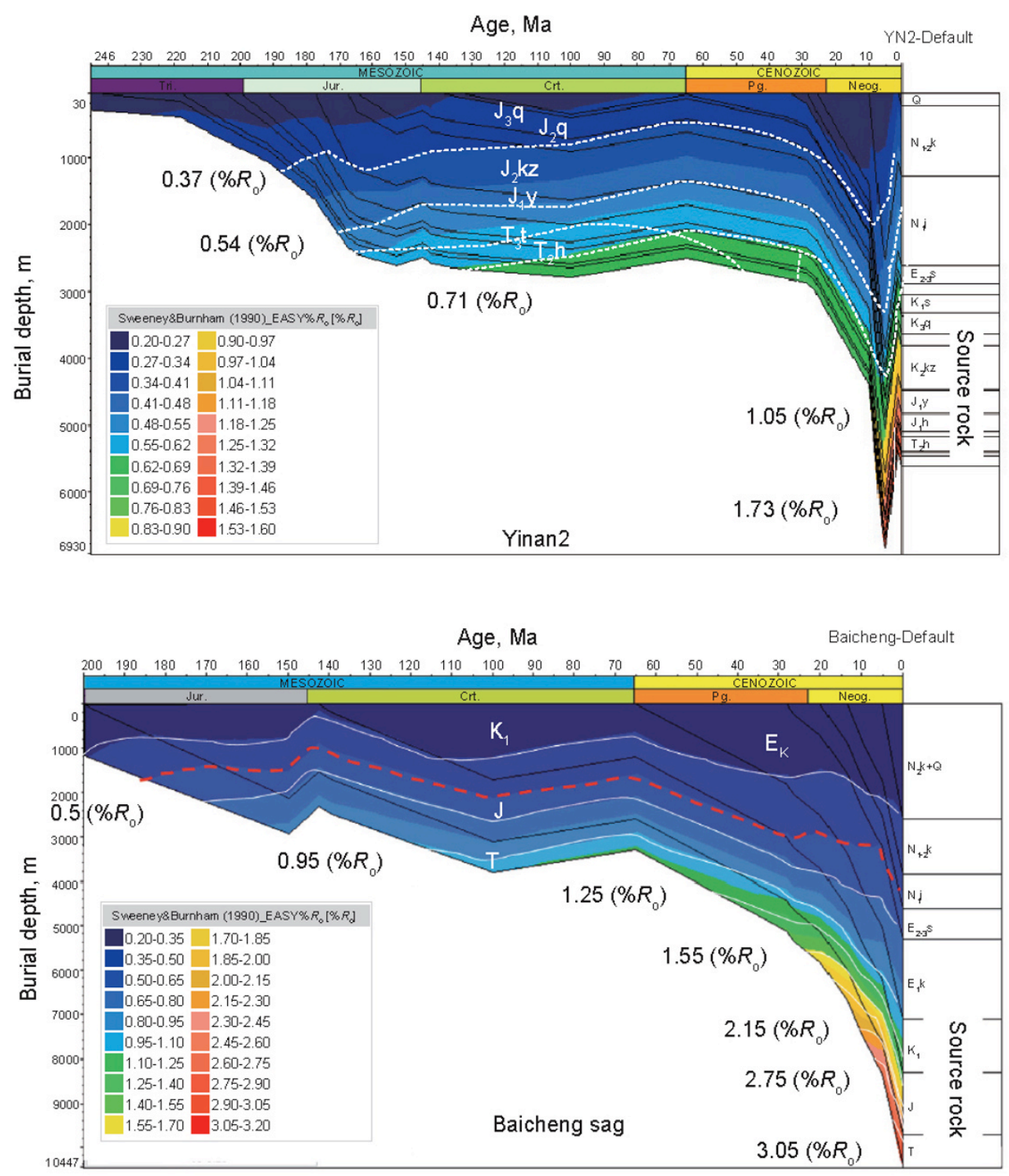

Fig. 3 Evolution history of different tectonic belts in the Kuqa Foreland Basin 


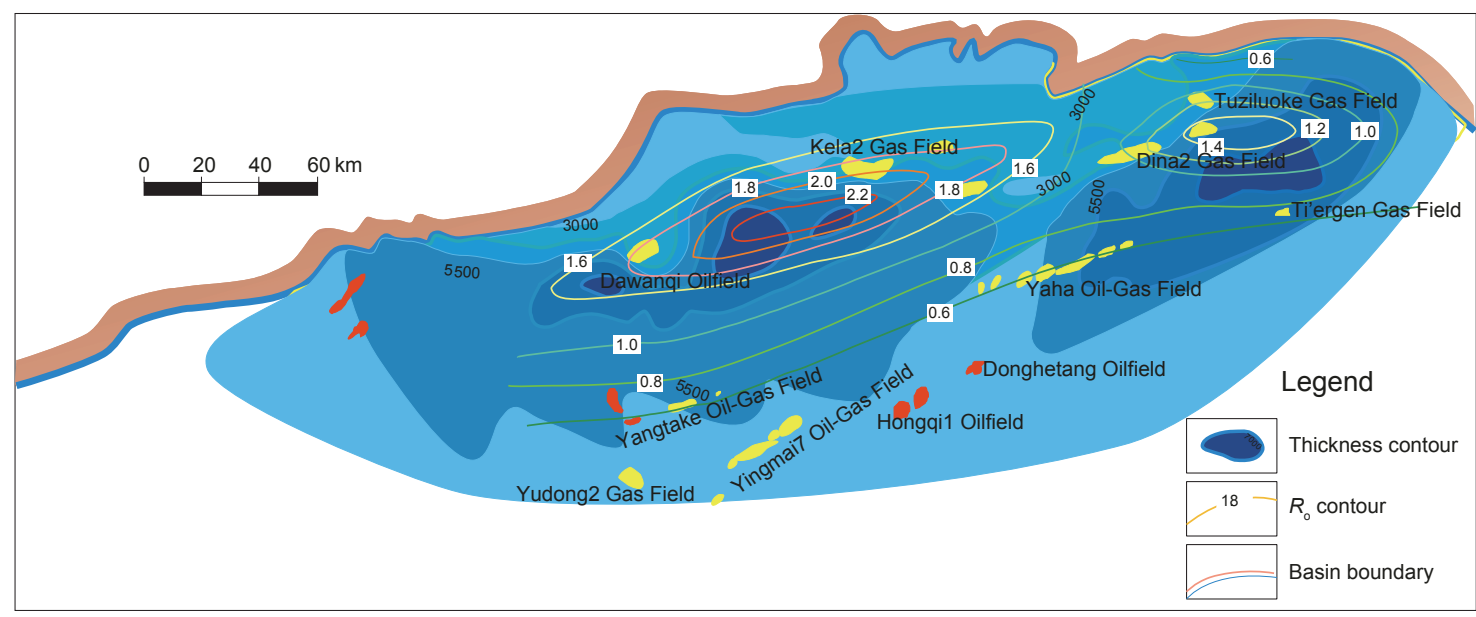

Fig. 4 Relationship between neotectonic layer thickness and Jurassic source rock maturity as well as hydrocarbon distribution in the Kuqa Foreland Basin

\subsection{Neotectonic movement can form new reservoir and improve the properties of old reservoir}

"New structures" mean the geological structures that were formed in the neotectonic movement, such as folds, faults, and fault blocks. The "neotectonic strata" mean the strata that have been formed since the Neogene, and the strata that deposited both before and during the Paleogene can be called "old tectonic strata" correspondingly.

New reservoirs can be formed in the neotectonic strata, for example, oil and gas have been found in neotectonic strata in Tuziluoke and Dawanqi areas. The statistics of hydrocarbon reserves show that a considerable amount of oil and gas has been found in the neotectonic strata in the Kuqa Foreland Basin, and the oil reserves are relatively larger. The proved gas reserves that are found in the neotectonic strata account for $5 \%$ of the total reserves, while the proved oil reserves account for $27 \%$.

The reservoir properties of old tectonic strata can be improved by tectonic uplift in the neotectonic movement period (Jiang et al, 2004; 2006). The reservoir porosity and permeability were decreased by compaction and intense lateral compression, but the fractures that were caused by the compression can improve the reservoir properties (Fig. 5). Hydrocarbon accumulated in the Cretaceous and Quaternary reservoirs in the Kuqa Foreland Basin, and some oil and gas are also found in the Jurassic strata. Paleogene strata host the main reservoirs, such as the large gas fields of Kela2 and Dina2.

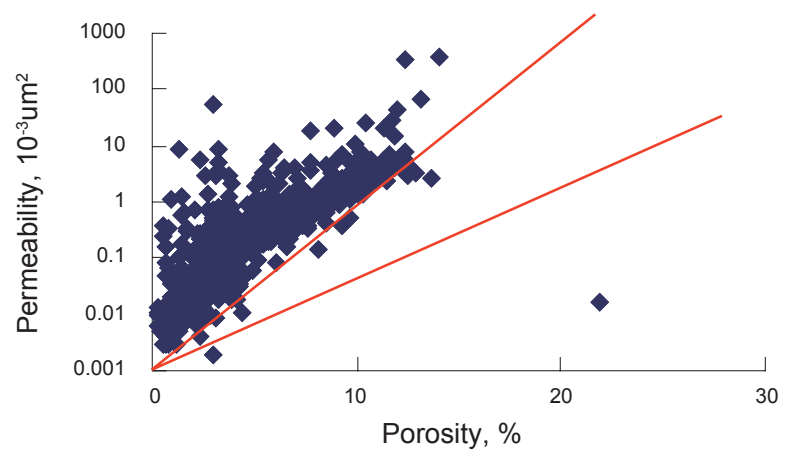

Fig. 5 Porosity-permeability relationship of Jurassic reservoir in the eastern Kuqa Basin

\subsection{Gypsum cap rock serves as an important factor in the formation of large gas fields in the Kuqa Foreland Basin}

Two sets of regional cap rocks developed in the Cenozoic strata in the Kuqa Foreland Basin. One is the gypsum mudstone cap rock of Paleogene Kumugeliemu and Suweiyi formations, and the other is the gypsum mudstone cap rock of Neogene Jidike Formation. The Paleogene cap rock is mainly distributed in the west of the Kuqa Basin. The gypsum-salt bed flowed under the effect of neotectonic movement, which changed the local distribution of the bed and influenced the preservation of oil and gas in underlying strata. Large gas fields were easily formed in the places where the gypsumsalt evaporite bed was thick, and some gas fields such as Kela2, Dawanqi and Yaha were found in such places. The favorable Paleogene cap rock was mainly distributed in the east preserved hydrocarbon well and made great contribution to the formation of the Dina2 Gas Field.

Coal cap rock is also developed in a few areas of the Kuqa Foreland Basin. The Mesozoic coal cap rock is destroyed in the neotectonic movement and is a poor barrier because the strata are cut by faults.

\subsection{Neotectonic movement leads to various traps in the Kuqa Foreland Basin}

Under the control of neotectonic movement, large numbers of traps related to faults were formed in the Kuqa Basin, and the final shape of the early traps was made. Currently, more than 80 traps have been found in the Kuqa Foreland Basin. Of these 69 (86\%) are structural traps. They include anticline, fault-anticline, fault nose and fault block traps. All of the large oil and gas fields in the Kuqa Basin are in structural traps. The horizontal distribution of these traps is characterized by zonation, and they are mainly distributed in the Ke-Yi tectonic belt, Qiulitage tectonic belt, southern foreland slope belt and the two sides of the Gumubiezi fracture in the Wushi sag.

The structural traps in the Kuqa Foreland Basin are formed continuously and progressively from Neogene to Quaternary. The traps were formed gradually later, from orogenic belt to foreland depression belt, namely, from north to south. 


\subsection{Fractures formed in the neotectonic movement provide migration pathways for hydrocarbon}

The main hydrocarbon migration pathways in the Kuqa Foreland Basin are faults, unconformity surfaces and sand bodies. Faults are important pathways for vertical migration, and mainly develop in the Ke-Yi and northern Qiulitage tectonic belts in the north of the basin. Unconformity surfaces and sand bodies are main pathways for lateral migration, and are relevant to the oil and gas of the Qiulitage tectonic belt in the south of the basin.

There are two fracture systems (above salt and below salt) developed in the Kuqa Foreland Basin. The faults of the two fracture systems are inherited but different. In the fracture system above salt, the fractures that break the neotectonic strata must be formed in the neotectonic movement period, and most of the fractures below salt are reactivated because of the neotectonic movement (Fig. 1). The study indicates that oil and gas are mainly distributed near the fractures, especially the fractures that developed in both the neotectonic strata and the old strata, such as Kela2 and Kela3 gas fields near the Kuba and $\mathrm{Tu}-\mathrm{Ka}$ fractures, and oil and gas fields in the southern slope belt. The distribution of fractures plays an important role in controlling the reservoirs (Jiang et al, 2005).

The hydrocarbon distribution in the Kuqa Foreland Basin has a large range vertically because faults connected the source rock and the reservoirs during the neotectonic movement. Oil and gas can be found from Mesozoic to Quaternary strata, as long as the strata are cut by the faults.

\subsection{Tectonic compression and overpressure release of source rock during the neotectonic movement period provide adequate driving force for hydrocarbon migration}

Most of the hydrocarbon reservoirs in the Kuqa Foreland
Basin are characterized by overpressure. Rapid sedimentation and compaction, tectonic compression and a large quantity of hydrocarbon generation and expulsion are considered as the main factors that lead to the formation of overpressure (Wang et al, 1997; Zhu et al, 2006; Song et al, 2006; Shi et al, 2007).

Qualitative analysis shows that tectonic compression can cause abnormally high pressure (Song et al, 2000). Tectonic compression made different contributions to overpressure in different tectonic belts in the Kuqa Depression. The contribution ratio made by tectonic compression to overpressure can reach $55 \%-80 \%$ in the Ke-Yi tectonic belt, while it is only $22 \%-39 \%$ in the Yangxia sag which has a weak compression (Qi et al, 2009). Thus the main cause of overpressure is tectonic compression in the region where tectonic movement is intense and it is subsidence in the sag.

The deposition of thick overlying neotectonic strata during the neotectonic movement period is also an important factor in causing overpressure. First, rapid subsidence made the source rock become mature in a short time and a large quantity of hydrocarbon was generated and expelled. Second, the regional cap rock played an important role in the preservation of overpressure. Most of the large oil and gas fields are distributed around the depositional center of neotectonic strata (Fig. 4).

\subsection{Time-space matching between accumulation elements and accumulation process during the neotectonic movement period determines the late hydrocarbon accumulation of large gas fields in the Kuqa Foreland Basin}

The influence of neotectonic movement on late hydrocarbon accumulation is shown in Fig. 6. The intense tectonic movement made all kinds of accumulation elements match well in a short time.

\begin{tabular}{|c|c|c|c|c|c|c|c|c|}
\hline $\mathrm{T}$ & & J & $\mathrm{K}_{1}$ & $\mathrm{~K}_{2}$ & E & $N_{1} N_{1} N_{2}^{N_{2} K}$ & \multicolumn{2}{|c|}{$\begin{array}{l}\text { Geological } \\
\text { age }\end{array}$} \\
\hline (Ma) & 220 & 180 & 140 & 100 & 60 & 20 & 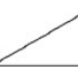 & $\begin{array}{l}\text { Accumulation } \\
\text { event }\end{array}$ \\
\hline & & & & & & & \multicolumn{2}{|c|}{ Source rock } \\
\hline & & & & & & & \multicolumn{2}{|c|}{ Reservoir } \\
\hline & & & & & & & \multicolumn{2}{|c|}{ Cap rock } \\
\hline & & & & & & & \multicolumn{2}{|c|}{ Surface cover } \\
\hline 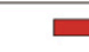 & & & & & & a & Oil & \multirow{2}{*}{$\begin{array}{c}\text { Hydrocarbon } \\
\text { generation } \\
\text { history }\end{array}$} \\
\hline & & & & & & & Gas & \\
\hline & & & & \multicolumn{3}{|c|}{-} & \multicolumn{2}{|c|}{ Tectonic movement } \\
\hline & & & & & & --[ & \multicolumn{2}{|c|}{ Trap formation } \\
\hline & & & & \multicolumn{3}{|c|}{ - --------------------- } & Oil & \multirow{2}{*}{$\begin{array}{c}\text { Migration } \\
\text { accumulation }\end{array}$} \\
\hline & & & & & & Gas & \\
\hline & & & & & & & Oil & \multirow{2}{*}{ Duration } \\
\hline ᄃ & & & & & & & Gas & \\
\hline & & & & & & - & Oil & \multirow{2}{*}{$\begin{array}{l}\text { Preservation } \\
\text { time }\end{array}$} \\
\hline & & & & & & ᄃ & Gas & \\
\hline & & & & & & \multicolumn{2}{|c|}{$0 \mathrm{Ma} \triangle \mathrm{Oil}$} & \multirow{2}{*}{$\begin{array}{l}\text { Critical } \\
\text { moment }\end{array}$} \\
\hline & & & & & & $2 \mathrm{Ma} \triangle$ & Gas & \\
\hline
\end{tabular}

Fig. 6 Accumulation events of oil and gas fields in the Kuqa Foreland Basin 
The reservoirs in foreland basins are mainly structural reservoirs which are far from the source rock. Faults are the vertical migration pathways, and the reservoirs are characterized by overpressure. So the typical accumulation characteristics can be summarized as "two periods matching, fault and pressure controlling, episodic charging and late accumulation". The so-called "two periods matching" means the matching between trap formation period and hydrocarbon generation and expulsion period, which solves the problem of basic material and accumulation space for reservoir formation. "Fault and pressure controlling" solves the problem about migration pathways and driving force, which means that the mature hydrocarbon mainly migrates through the faults driven by high pressure. Hydrocarbon migration is episodic, and the hydrocarbon accumulation is the result of late adjustment of oil and gas.

A large number of studies have shown that the hydrocarbon accumulation in the Kuqa Foreland Basin occurred late in the history of the basin (Song and Wang, 2003; Pang, 2008; Jiang et al, 2007; Li et al, 2006; Jia et al, 2006; Zhao et al, 2005). Most of the hydrocarbon accumulated in the Kuqa period, which was beneficial to the formation of large gas fields.

\section{Accumulation model in the Kuqa Foreland Basin under the control of neotectonic movement}

There are two models of accumulation in the Kuqa

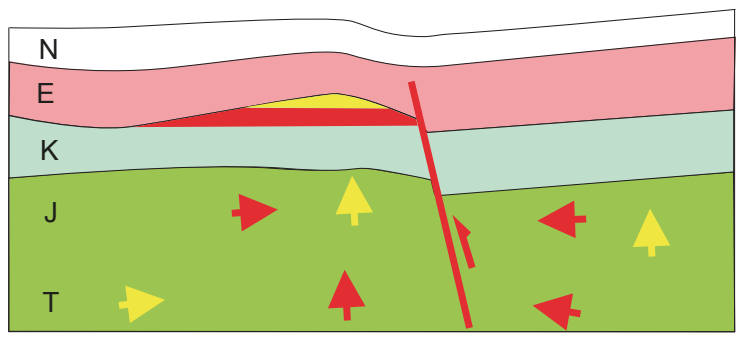

(a) Before neotectonic movement

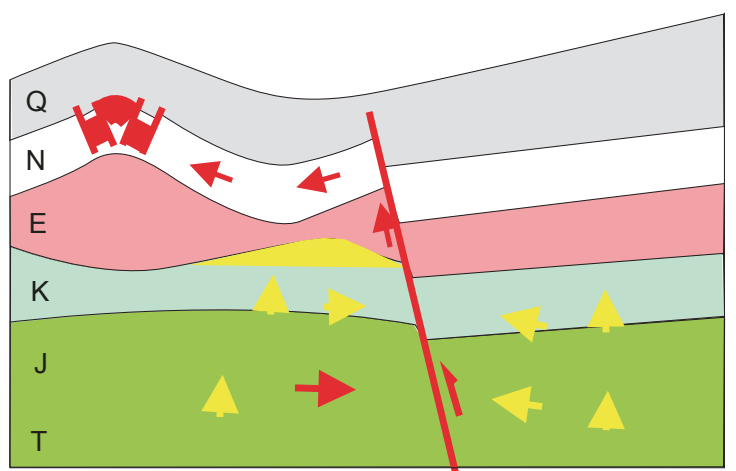

(c) Buoyancy adjustment period

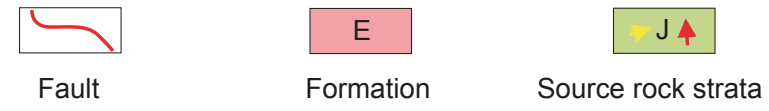

Foreland Basin under the control of neotectonic movement. One is the "above salt" model (neotectonic strata) represented by the Dawanqi oilfield, the other is the "below salt" model (old strata) represented by the Kela2 and Dina2 gas fields, where "salt" is referring to the prominent gypsum-salt evaporite layer.

\subsection{Above salt (neotectonic strata) model in the Kuqa Foreland Basin during the neotectonic movement period}

At the beginning of the neotectonic movement, the Triassic and Jurassic source rocks entered the stage of mature oil generation and generated little gas. At this time, the tectonic movement was weak and the structures in the neotectonic strata above salt were seldom formed or just begun to develop. The faults did not cut the overlying gypsum-salt cap rock and hydrocarbon accumulated in the strata below. Differentiation of the hydrocarbon in the reservoir occurred under the action of buoyancy (Fig. 7(a)). During the intense neotectonic movement period, structural traps were formed in the neotectonic strata under the effect of strong overthrusting. The structural high points are different in the neotectonic strata and the old strata, and new anticlines formed above the old syncline and far away from faults. The faults were activated again and cut the regional gypsumsalt cap rock, the hydrocarbon under the rock salt strata migrated to shallower positions through the faults under the effect of hydrocarbon generation and tectonic compression (Fig. 7(b)). Subsequently, the oil and gas in the neotectonic

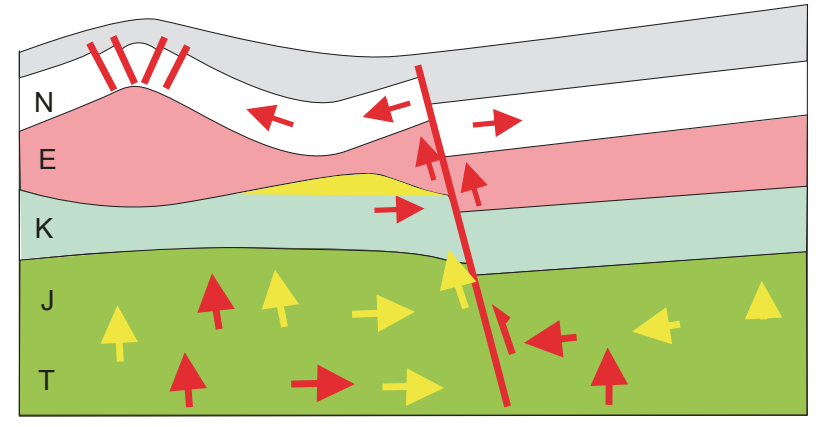

(b) Episodic charging period

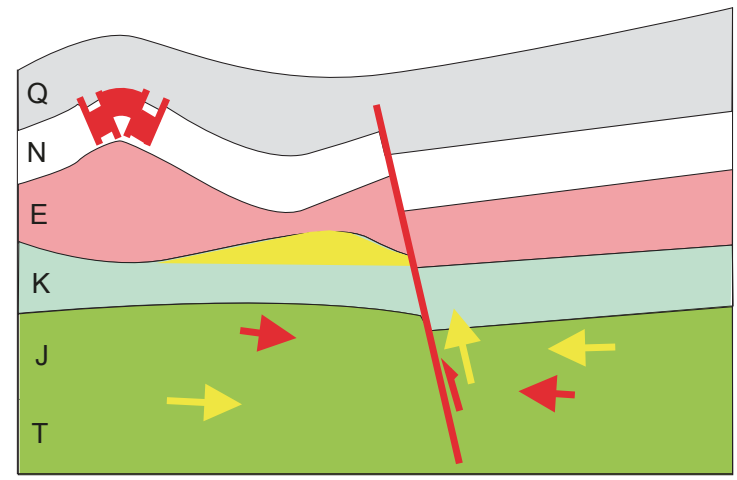

(d) Late hydrocarbon accumulation period

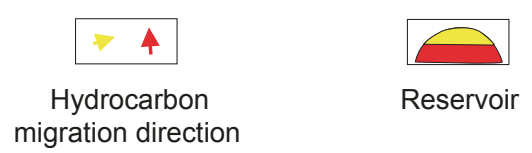

Fig. 7 Late accumulation model of strata above salt in the Kuqa Foreland Basin 
strata migrated through the unconformity surfaces and strata pathways to the high position in the anticline and accumulated under the effect of buoyancy (Fig. 7(c) and (d)). At the same time, the hydrocarbon generation of deep source rock and tectonic recompression made material and energy preparation for a new round of episodic hydrocarbon charging. This kind of hydrocarbon accumulation mainly occurs near the mountain front where thrust-nappe is intense because the sealing condition in the shallow position is not good. Light fractions dissipated easily, and methane content of high-position reservoirs is less than that of low-position reservoirs.

\subsection{Below salt (neotectonic strata) model in the Kuqa Foreland Basin during the neotectonic movement period}

The reservoirs below salt in the Kuqa Foreland Basin mainly accumulate in the old strata, such as the Dina2 and Kela2 gas fields. There is also hydrocarbon discovered in the neotectonic strata below salt, such as the Tuziluoke gas

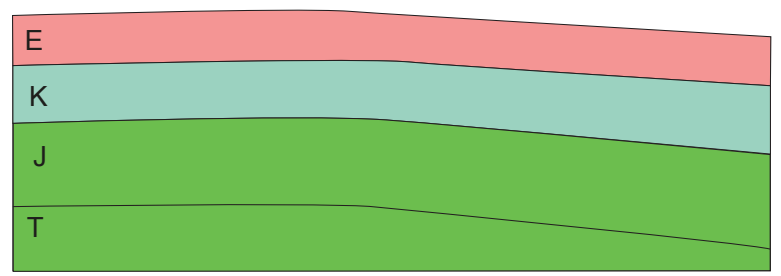

(a) Before neotectonic movement

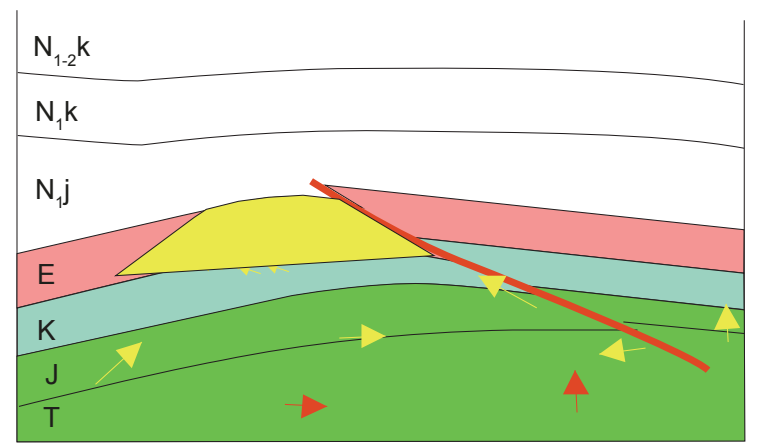

(c) Buoyancy adjustment period field whose reservoir and cap rock is mudstone of the Jidike Formation.

Before the neotectonic movement, the tectonic movement was weak, traps were not formed, faults were not developed, the maturity of hydrocarbon source rock was low and the hydrocarbon generation amount was limited (Fig. 8(a)). When the neotectonic movement began, tectonic movement became intense, and anticline traps began to form. The source rock generated large amounts of hydrocarbon, and the lower source rock overpressure system was formed. Faults that connected to source rock were formed or activated again, and hydrocarbon migrated to reservoirs in an episodic charging way driven by high pressure (Fig. 8(b)). The hydrocarbon that entered reservoirs began to accumulate in the high positions of the anticline under the effect of buoyancy (Fig. 8(c)). With the further tectonic compression, the close-height of the anticline increased gradually and overpressure might have been formed in the compression process. The hydrocarbon accumulation process adjusted continuously and present gas fields below salt were eventually formed (Fig. 8(d)).

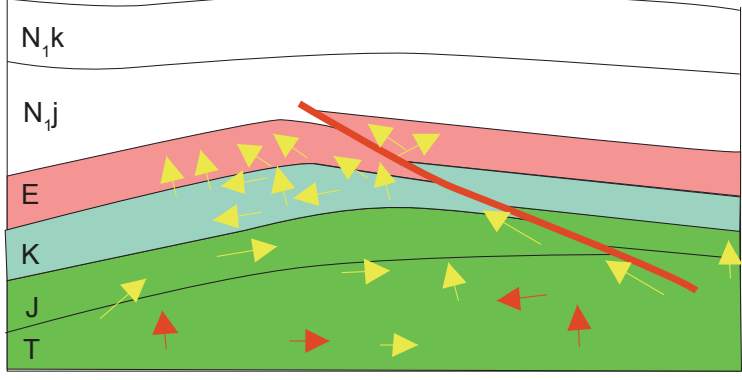

(b) Episodic charging period

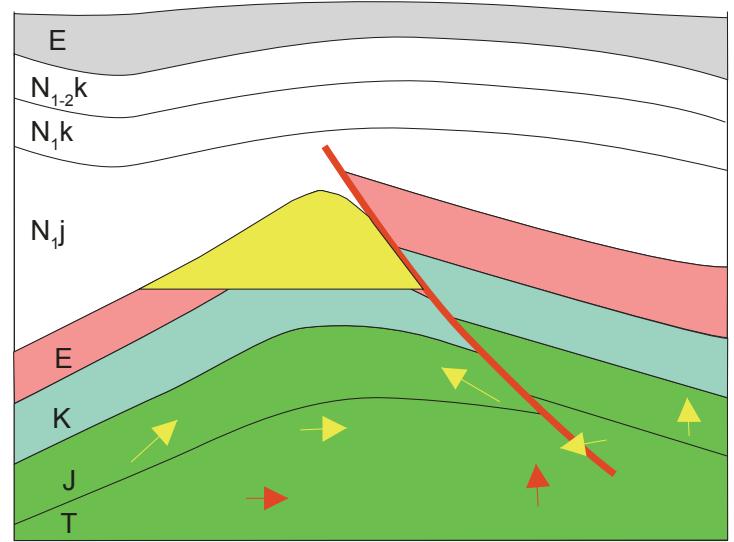

(d) Late hydrocarbon accumulation period

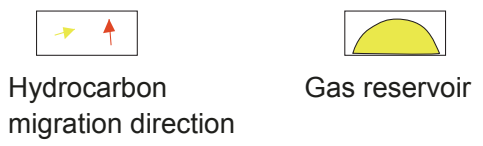

Fig. 8 Late accumulation model of strata below salt in the Kuqa Foreland Basin

\section{Conclusions}

1) The neotectonic movement in the Kuqa Foreland Basin began in the Neogene. This basin subsided continuously and rapidly, and the maximum subsidence rate reached 1,200 $\mathrm{m} / \mathrm{Ma}$ in the Baicheng sag during the Kuqa period. Structures are mainly fractures associated with folds in the northern basin, mainly folds associated with fractures in the central part of this basin, and only folds in the southern basin.

2) Neotectonic movement controlled the evolution of accumulation elements. Hydrocarbon source rock matured rapidly, and $R_{\mathrm{o}}$ reached $1.8 \%-3.0 \%$. The gas generation 
peaks of Triassic and Jurassic source rocks appeared during the neotectonic movement period. New reservoirs were formed because of the deposition of neotectonic strata and the fractures formed by the tectonic compression improved the properties of reservoirs in the old strata. Intense tectonic movements led to the formation of fault-related traps, and $86 \%$ of the traps in the Kuqa Basin are structural traps. Faults served as the main migration pathways for hydrocarbon, and large fractures controlled the size and distribution of hydrocarbon reservoirs. Intense lateral compression, thick neotectonic strata deposition and rapid hydrocarbon generation led to source rock overpressure and provided the driving force for hydrocarbon migration.

3) The influence of neotectonic movement on late hydrocarbon was considerable. The intense tectonic movement made all kinds of accumulation elements match well in a short time. The typical accumulation model can be summarized as "two periods matching, fault and pressure controlling, episodic charging and late accumulation".

\section{Acknowledgements}

This study was supported by the Foundation Project of State Key Laboratory of Petroleum Resources and Prospecting (PRPDX2008-05) and the "973" National Key Basic Research Program (2006CB202308).

\section{References}

Cheng D L, Jing $\mathrm{C} \mathrm{R}$ and Zhong X B. On neotectonic movement and crus stability. Journal of Xianning College. 2007. 27(6): 111-114 (in Chinese)

Gao R Q and Zhao Z Z. China New Area Exploration (Vol. 1): Exploration of Large Gas Fields in the Kuqa Depression in Tarim Basin. Beijing: Petroleum Industry Press. 2001 (in Chinese)

Glover C and Robertson A. Neotectonic intersection of the Aegean and Cyprus tectonic arcs: extensional and strike-slip faulting in the Isparta Angle, SW Turkey. Tectonophysics. 1998. 298(1-3): 103-132

Granja H M, Ribeiro I C, de Carvalho G S, et al. Some neotectonic indicators in Quaternary formations of the northwest coastal zone of Portugal. Physics and Chemistry of the Earth, Part A: Solid Earth and Geodesy. 1999. 24(4): 323-336

Guo Z Q and Shi J H. Characteristics of the hydrocarbon system in Qaidam Basin with an active new structural movement. Petroleum Geology \& Oilfield Development in Daqing. 2001. 20(1): 9-12 (in Chinese)

Guo Z Q, Xu W F and Peng W. Continental crust and basic characteristics of petroleum systems in western China. Xinjiang Petroleum Geology. 1999. 20(5): 336-343 (in Chinese)

Hao F, Zou H Y, Gong Z S, et al. The material and energy effects of neotectonics/late-stage tectonics and petroleum accumulation. Acta Geological Sinica. 2006. 80(3): 424-431 (in Chinese)

Jia C Z, He D F and Shi X. Himalayan movement and late hydrocarbon accumulation. In: Symposium on Control of Himalayan Movement on Sedimentary Basins and Late Hydrocarbon Accumulation in China. 2004. 11-48 (in Chinese)

Jia C Z, He D F, Shi X, et al. Characteristics of late hydrocarbon accumulation in China. Science in China (Series D: Earth Sciences). 2006. 36(5): 412-420 (in Chinese)

Jia X L, Zhao H J, Zhang S Q, et al. New tectonic movement and its ecological environment influences in Yangtze River source area. Plateau Earthquake Research. 2008. 20(2): 34-40 (in Chinese)

Jiang F J, Jiang Z X, Pang X Q, et al. Hydrocarbon accumulation conditions and advantageous exploration targets in foreland basins of central-western
China. Xinjiang Petroleum Geology. 2007. 28(1): 1-6 (in Chinese)

Jiang Z X, Pang X Q, Jin Z J, et al. Relationship between pore variation of reservoir and rebounding of sandstone during uplift and its application to the Daqing Oilfield. Earth Science-Journal of China University of Geosciences. 2004. 29(4): 420-427 (in Chinese)

Jiang Z X, Pang X Q, Tian F H, et al. Tectonic uplifting and pressure releasing and the effect of hydrocarbon accumulation. Journal of Jianghan Petroleum Institute. 2006. 28(3): 47-50 (in Chinese)

Jiang Z X, Pang X Q, Zeng J H, et al. Research on types of the dominant migration pathways and their physical simulation experiments. Earth Science Frontiers. 2005. 12(4): 507-516 (in Chinese)

Jin W Z, Tang L J, Wang Q H, et al. Cenozoic tectonic evolution of the eastern Qiulitage structural belt, Kuqa foreland basin in Xinjiang. Chinese Journal of Geology. 2007. 42(3): 444-454 (in Chinese)

Kirillova G L. Late Mesozoic-Cenozoic sedimentary basins of active continental margin of Southeast Russia: paleogeography, tectonics, and coal-oil-gas presence. Marine and Petroleum Geology. 2003. 20(3-4): 385-397

Kontorovich V A. The Meso-Cenozoic tectonics and petroleum potential of West Siberia. Russian Geology and Geophysics. 2009. 50(4): 346-357

Li D W. Neotectonics and Hydrocarbon Accumulation in the Huanghua Depression. Wuhan: China University of Geosciences Press. 2006 (in Chinese)

Li H Y, Jiang Z X, Lin S G, et al. The distribution rules of oil and gas in the foreland basins of central-western China. West China Petroleum Geosciences. 2006. 2(4): 368-373 (in Chinese)

Liu Z H, Lu H F, Jia C Z, et al. Determination of orogency time in the Kuqa foreland thrust belt. Earth Science Frontiers. 1999. 6(4): 236-241 (in Chinese)

Liu Z H, Lu H F, Li X J, et al. Tectonic evolution of the Kuqa rejuvenated foreland basin. Chinese Journal of Geology. 2000. 35(4): $482-492$ (in Chinese)

Lu H F, Jia D, Chen C M, et al. Nature and timing of the Kuqa Cenozoic structures. Earth Science Frontiers. 1999. 6(4): 215-221 (in Chinese)

Lykousis V, Anagnostou C, Pavlakis P, et al. Quaternary sedimentary history and neotectonic evolution of the eastern part of Central Aegean Sea, Greece. Marine Geology. 1995. 128(1): 59-71

Pang X Q. Accumulation mechanism and distribution rule of hydrocarbon in typical superimposed basins in western China. Oil \& Gas Geology. 2008. 29(2): 157-158 (in Chinese)

Pang X Q, Gao J B, Lü X X, et al. Reservoir accumulation pattern of multifactor recombination and procession superimposition and its application in the Tarim Basin. Acta Petrolei Sinica. 2008. 29(2): 159-172 (in Chinese)

Qi J F, Lei G L, Li M G, et al. A model of contractional structure for transition belt between the Kuche Depression and the Southern Tianshan Uplift. Earth Science Frontiers. 2009. 16(3): 120-128 (in Chinese)

Qiang Z J and Wang H T. Study of Active Structure. Beijing: Earthquake Press. 1992 (in Chinese)

Qin S F, Dai J X, Zhao J Z, et al. Control of the neotectonics in China on natural gas accumulation. Geological Review. 2006. 52(1): $94-99$ (in Chinese)

Redfield T F, Torsvik T H, Andriessen P A M, et al. Mesozoic and Cenozoic tectonics of the Møre Trøndelag Fault Complex, central Norway: constraints from new apatite fission track data. Physics and Chemistry of the Earth, Parts A/B/C. 2004. 29(10): 673-682

Shi W Z, Chen H H and He S. Quantitative evaluation on contribution of structural compression to overpressure and analysis of origin of overpressure in the Kuqa Depression. Acta Petrolei Sinica. 2007. 28(6): 60-65 (in Chinese)

Song Y and Wang X S. The controlling action of modern structural movement on the late accumulation of natural gas. Natural Gas Geoscience. 2003. 14(2): 103-106 (in Chinese)

Song Y, Fang D Q and Xia X Y. The formation of abnormal pressure and its 
relationship with natural gas accumulation. Achievements of the program "Exploration \& Development Study of Large and Middle Gas Fields in China”. 2000 (in Chinese)

Song Y, Hong F, Xia X Y, et al. Syngenesis relationship between abnormal overpressure and gas pool formation - with the Kuqa Depression as an example. Petroleum Exploration and Development. 2006. 33(3): 303-308 (in Chinese)

Sun J Z, Li L B, Zhou X Y, et al. Analysis on the typical structural styles and deformation mechanism of the Kelasu tectonic zone in the Kuqa Depression of the Tarim Basin. Petroleum Geology \& Experiment. 2003. 25(3): 247-250 (in Chinese)

Tang L J, Jia C Z, Pi X J, et al. Salt-related structural styles of fold belts in the Kuqa foreland basin. Science in China, Series D. 2003. 33(1): 38-46 (in Chinese)

Tang L J, Wan G M, Wang Q H, et al. Tectonic evolution of the western Qiulitage tectonic belt in the Mesozoic and Cenozoic, Kuqa Depression. Journal of Southwest Petroleum University (Science \& Technology Edition). 2008. 30(2): 167-171 (in Chinese)

Wang X S, Li J C, Wang S M, et al. Oil and gas accumulation and structural stress field in the Tarim Basin. Acta Petrolei Sinica. 1997. 18(1): $23-27$ (in Chinese)

Xu Z P, Wu C, Ma L K, et al. Salt-related structure styles and their genetic mechanisms in the middle of the Kuqa Depression. Natural Gas Geoscience. 2009. 20(3): 356-361 (in Chinese)

Yu Y X, Tang L J, Wang Q H, et al. Salt structures and forming models of hydrocarbon pools in the Kuqa Depression. Coal Geology \& Exploration. 2005. 33(6): 5-9 (in Chinese)
Zhang J R, Chen P and Zhong J W. Neotectonics characteristics of the Yanshan water reservoir and their relationship with engineering construction. Henan Water Resources \& South-to-North Water Diversion. 2007. (2): 33-34 (in Chinese)

Zhang Z P, Lin W and Wang Q C. Progressive structural evolution of the Kelasu-Yiqikelike structural belt in the Kuqa Depression. Geotectonica et Metallogenia. 2003. 27(4): 327-336 (in Chinese)

Zhao M J, Song Y, Qin S F, et al. The multi-stage formation of oil-gas pools and late-stage accumulation of gas in the foreland basins in central and western China. Earth Science Frontiers. 2005. 12(4): 525-532 (in Chinese)

Zheng M, Meng Z F, Li X B, et al. Characteristics of the hydrocarbon system in the Kuqa Basin with an active new structural movement. Acta Scientiarum Naturalium Universitatis Sunyatseni. 2005. 44(z1): 305-310 (in Chinese)

Zheng M, Peng G X, Lei G L, et al. Structural pattern and its control on hydrocarbon accumulations in the Wushi Sag, Kuche Depression, Tarim Basin. Petroleum Exploration and Development. 2008. 35(4): 444-451 (in Chinese)

Zhou X X. Oil and gas pool forming process and tectonic evolution of Cenozoic in the Kuqa petroleum system of the Tarim Basin. Journal of Palaeogeography. 2002. 4(1): 75-82 (in Chinese)

Zhu R, Lou Z H and Jin A M. A study of dynamic process of gas reservoiring in the Mesozoic and Cenozoic in the Kuqa Depression. Natural Gas Industry. 2006. 26(5): 5-7 (in Chinese)

(Edited by Hao Jie) 